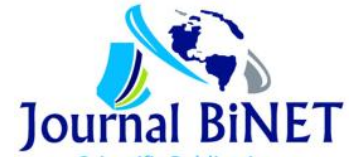

Scientific Publication
Vol. 07, Issue 02: 659-668

Journal of Bioscience and Agriculture Research

Home page: www.journalbinet.com/jbar-journal.html

\title{
Effect of greywater irrigation on wheat and mung-bean production in clayey-loam soil
}

\author{
Md. Moinul Hosain Oliver and S. M. Iqbal Hossain
}

\author{
Dept. of Agricultural Engineering, Bangabandhu Sheikh Mujibur Rahman Agricultural \\ University, Gazipur 1706, Bangladesh \\ 凶oliver@bsmrau.edu.bd (Oliver, M. M. H.), \& +88029205310-14; Ext. 2117, Published: 15 April 2016
}

\begin{abstract}
Greywater is considered as a viable and alternative source of irrigation in many parts of the world. In Bangladesh, it is mainly the marginal farming community who use untreated urban greywater for irrigation. However, very few crop and soil specific investigations on greywater use have been carried out in Bangladesh. This study reports the results of two agronomic experiments carried out to quantify the effects of greywater irrigation on the production of two popular winter crops in Bangladesh i.e., mungbean and wheat. It also reports the status of the nutritional balance of soil due to greywater irrigation in two consecutive years i.e., 2012 and 2013. The experiment with each crop was conducted in random blocks replicating each of the six greywater treatments thrice. The results highlighted the fact that raw use of greywater was not beneficial for mungbean. On the other hand, second highest yield of wheat was obtained from the raw greywater treatment. Nonetheless, the highest crop yield was found when greywater (75\%) was diluted with freshwater (25\%) in a combined use. Crops irrigated with alum-treated greywater produced moderate yields. Considering the health risks associated with raw use of greywater, the alum-treatment of greywater appears to be a viable alternative to the farmers. It was found that unregulated use of greywater resource could lead to salinity problems in clayey loam soil. In particular, raw greywater irrigation was shown to be leading a buildup of $P$ in the soil which could pose a potential environmental risk. This study recommends that crops good at up-taking phosphorus from the soil should be prioritized in greywater irrigation schemes.
\end{abstract}

Key Words: Recycled water, Urban greywater, Irrigation, Soil nutrients and Phosphorus buildup

Please cite this article as: Oliver, M. M. H. \& Hossain, S. M. I. (2016). Effect of greywater irrigation on wheat and mung-bean production in clayey-loam soil. Journal of Bioscience and Agriculture Research, 07(02), 659668.

This article is distributed under terms of a Creative Common Attribution 4.0 International License.

\section{Introduction}

The urban and the wider metropolitan areas of Bangladesh generate an average of $160 \mathrm{~L} / \mathrm{capita} /$ day of greywater (Tamanna et al., 2011) all the year round. Greywater is usually defined as non-industrial wastewater generated from domestic processes, i.e., laundry, bathing and from the kitchen. In fact, any water from household use excluding the water used to flush toilets can be termed as greywater. It is a major fraction (75\%) of domestic liquid waste which is generally less polluted than other types of 
wastewater (Eriksson et al., 2002). Greywater production in the developed nations is estimated to be 60-70\% (Casanova et al., 2001; Christova-Boal et al., 1996) of the average domestic water requirement (240-260 L/capita/day). In Bangladesh, greywater production is estimated to 147-172 L/capita/day (lpcd) as reported by Tamanna et al. (2011). In almost all the cases, household greywater from the Bangladeshi households is released to the environment without any treatment. It ultimately finds its way through the municipal drains to a nearby water body. Farmers in the per-urban areas of Bangladesh often use this wastewater to irrigate their field (Ahmad \& Goni, 2010). Such use has been popular amongst the poor farming community during the last three decades.

In Bangladesh, Gazipur is amongst the most densely populated municipalities (BBS, 2015) producing huge amount of greywater. Farmers in the outskirts of Gazipur use this water for irrigation during the dry (Boro) season. Since irrigation water enjoys some relaxation regarding its quality (FAO, 2003; Trooien \& Hills, 2007), greywater irrigation can actually be a viable alternative to the traditional groundwater sources. Greywater irrigation can also ensure safe disposal (Thamsen, 2009) of poor quality water that is rich in nutrients. However, greywater irrigation must be done carefully so it does not jeopardize the potential crop yield and the human health. Although a rough guideline (Table 01) about greywater quality for irrigation exits (Oliver et al., 2014; Platzer et al., 2004), it does not detail the requirements of specific crops and soil types. Therefore, a site specific investigation is always recommended so that the nutritional value of greywater as irrigation water can be quantified for different crops.

Table 01. Greywater quality for the Agricultural Sector (Platzer et al., 2004)

\begin{tabular}{|l|l|l|l|}
\hline Parameters & Permissible Values & Parameters & Permissible Values \\
\hline $\mathrm{pH}$ & $6.5-8.5$ & COD & $200 \mathrm{mg} / \mathrm{L}$ \\
\hline Conductivity & $2000 \mu \mathrm{S} / \mathrm{cm}$ & Total Suspended Solid & $120 \mathrm{mg} / \mathrm{L}$ \\
\hline $\begin{array}{l}\text { Biochemical Oxygen Demand } \\
\left(B_{5}\right)\end{array}$ & $120 \mathrm{mg} / \mathrm{L}$ & F. Coliform & $1000(\mathrm{mpn} / 100 \mathrm{~mL})$ \\
\hline
\end{tabular}

The quality of greywater understandably depends on the type of domestic use. For instance, greywater from the kitchen and laundry usually have higher organic content (Li et al., 2009) compared to the other sources of domestic discharges. Consequently, kitchen and laundry discharges are termed as high-load greywater (E Friedler, 2004; Terpstra, 1999; Zavala et al., 2002). On the other hand, bath, shower and wash basin discharges are termed as low-load greywater. Tamanna et al. (2011) found the $\mathrm{pH}$ of greywater collected from the domestic sources of Dhaka varying from 6.43 to 7.35; color varying from 29 to 490 (Pt-Co); turbidity varying from 27.6 to 370 (ntu); chemical oxygen demand (COD) varying from 172 to 1307 (mg/l); and BOD varying from 16 to 750 (mg/l). Compared to the values presented in Table 01, Tamanna et al. (2011) concluded that only rinse water, basin water \& bathing water can be used for irrigation without any treatment. The ablution water from mosques was also reported to be usable for irrigation with no to minimum treatment (Al-Wabel, 2011; Prathapar et al., 2006).

The most common and the cheapest preliminary treatment of greywater can be achieved by using chemical coagulants (Šostar-Turk et al., 2005) followed by filtration and subsequent chlorination. Most common form of chemical processes have been shown in Table 02. Among these processes, alum coagulation appears to be the most feasible option for Bangladeshi farmers using the greywater. This is because, alum $\left(\mathrm{Al}_{2}\left(\mathrm{SO}_{4}\right)_{3} * 14 \mathrm{H}_{2} \mathrm{O}\right)$ is readily available in the local market and farmers have access to it. The rate of use to treat particular water samples needs to be decided at the point of use, and hence is site specific.

Table 02. Chemical treatment processes of greywater

\begin{tabular}{|l|l|}
\hline References & Proposed treatments \\
\hline Khatun and Amin (2011) & Alum coagulation+ chlorination + membrane filtration \\
\hline Skudi et al. (2011) & Alum coagulation+quartz sand filtration \\
\hline Eran Friedler et al. (2008) & Coagulation + sedimentation + UF + RO \\
\hline Pidou et al. (2008) & Coagulation with aluminium salt \\
\hline Šostar-Turk et al. (2005) & Coagulation + sand filter +GAC \\
\hline
\end{tabular}

Furthermore, greywater is rich in nutrients (Jarwal et al., 2006; Kunhikrishnan et al., 2012), and hence is considered to be profitable if used in combination with regular irrigation water. Given the potential 
benefit of greywater in conjunction with the groundwater resources, this experiment was designed to assess the effect of greywater irrigation on the yield and yield-contributing characters of wheat (Triticum aestivum) and mungbean (Vigna radiate L.) grown on a clayey loam soil. This paper also reports the results regarding changes in the nutritional balance of the soil brought about by greywater irrigation.

\section{Materials and Methods}

This field experimental research was carried out in two consecutive years; at the same season; in the same field of Bangabandhu Sheikh Mujibur Rahman Agricultural University (BSMRAU), Bangladesh during Winter/2012 and Winter/2013. The greywater was collected from the drainage system that runs nearly a kilometer within BSMRAU carrying the residential discharges to the far end of the university. Greywater samples were collected in triplicates from the canals for quality analysis. Water temperature, odor, total dissolved solid (TDS), total Alkalinity, total hardness and its color due to minerals and nitrogenous waste content ware observed as a measure of suspended matter. The concentration of common ions, i.e., Arsenic (As), Calcium (Ca), Chloride (C1), Iron (Fe), Magnesium $(\mathrm{Mg})$, Nitrate Nitrogen $\left(\mathrm{NO}_{3}-\mathrm{N}\right)$, Nine $(\mathrm{Zn})$, Potassium $(\mathrm{K})$, Sodium $(\mathrm{Na})$, were measured using ICP-MS (Vanhaecke, 2002; Voica et al., 2012). Sodium Adsorption Ratio (SAR), Phosphate $\left(\mathrm{PO}_{4}\right)$, Sulphate $\left(\mathrm{SO}_{4}\right)$ concentrations of the greywater were also determined following the standard procedure (ASTM, 2010, 2012). The 5-day biochemical oxygen demand $\left(\mathrm{BOD}_{5}\right)$, and the chemical oxygen demand (COD) of the greywater was also determined according to APHA (2005). After establishing the water characteristics, the soil samples were also collected from the field both before and after the agronomic experiment. in order to evaluate the changes in their nutritional balance in terms of $\mathrm{EC}, \mathrm{PH}, \mathrm{Ca}, \mathrm{Mg}, \mathrm{N}$, $\mathrm{P}, \mathrm{K}, \mathrm{Na}, \mathrm{Bo}$ and $\mathrm{Fe}$. The particle density of soil and moisture holding capacity were determined by gravimetric method in the laboratory.

Field Experiments: In order to quantify the effect of greywater irrigation on mungbean and wheat, two field experiments were carried out. The first agronomic experiment was focused on the production mungbean (BARI Mung-6) and the second on wheat (BARI Gom-26) subjected to different level of greywater irrigation treatments.

Table 03. Treatments used in the agronomic experiments with wheat and mung-bean

\begin{tabular}{|c|c|}
\hline T1 = Irrigation with good quality water (FAO, 2003) & $\begin{array}{l}\mathrm{T} 4=\text { Irrigation using fresh water }(25 \%)+ \\
\text { raw wastewater (75\%) }\end{array}$ \\
\hline $\mathrm{T} 2$ = Irrigation with raw wastewater & $\begin{aligned} \mathrm{T} 5 & =\text { Irrigation using fresh water }(50 \%)+ \\
& \text { raw wastewater }(50 \%)\end{aligned}$ \\
\hline $\begin{array}{l}\text { T3 = Irrigation using treated wastewater by Alum }\left(\mathrm{Al}_{2}\right. \\
\left.\qquad \mathrm{SO}_{4} * 14 \mathrm{H}_{2} \mathrm{O}\right)\end{array}$ & $\begin{array}{l}\mathrm{T} 6=\text { Irrigation using fresh water }(75 \%)+ \\
\text { raw wastewater }(25 \%)\end{array}$ \\
\hline
\end{tabular}

The experiment was laid out with random blocks ( $4 \mathrm{~m} \times 3 \mathrm{~m}$ ) with 6 treatments (Table 03) replicated thrice. This design would produce a total of 18 plots in the experimental field. The water management was carefully designed based on field requirement allowing management allowed deficit (MAD) of the moisture level to a maximum of $65 \%$ of the available moisture content below the field capacity. The climatological parameter, especially day to day rainfall and evaporation form the nearby Class $\mathrm{A}$ evaporation pan was measured regularly to incorporate with the calculation of field water requirement. The pan factor for early, vegetative and late stages of the crops was taken from the standard values provided by the Food and Agriculture Organization (FAO) of the United Nations (UN). Usual management practices were followed throughout the growing season. Fertilizers were applied to the field according to doses recommended by the Bangladesh Agricultural Research Council (BARC, 2005) for mung-bean, i.e., Urea @45 kg/ha, TSP @100kg/ha and MP@60kg/ha, and for wheat, i.e., Urea@160 kg/ha, TSP@25 kg/ha and MP@30 kg/ha.

Environmental Protection: Council of the European Communities (1986) prohibited the use of municipal wastewater from being used in agriculture unless specified requirements are fulfilled. This includes carting regulations in order to protect the environment (EPA Victoria, 2003; SA Health, 2012). Accordingly, we transported greywater using air tight tanks, chose the routes carefully, and applied with caution. The health protection of the labors engaged in collection and transportation of greywater 
was also a major concern. For this reason, the labors were supplied with gloves, masks and gumboots while working in the drains and also during application of water in the field.

\section{Results and Discussion}

\section{Characterization of greywater}

Greywater usually has variable qualities that depend on its source of origin (Khatun and Amin, 2011). However, the composite greywater in a particular area is said to have common characteristics although some reports have highlighted the presence of heavy metals in greywater. It is therefore important that before using greywater as a source of irrigation, the heavy metals should be looked for. This is particularly important in case of urban greywater reuse (Tamanna et al., 2011). The quality characteristics of the greywater used in the study has been shown in Table 04. The analysis negated the trace of any heavy metals in the composite greywater of BSMRAU. Other elements present in the greywater were well within the acceptable range (FAO, 2003; WHO, 1989) for it to be used as irrigation water.

The concentration of Iron $(2.2 \pm 0.3 \mathrm{mg} / \mathrm{L})$ was particularly found to be slightly higher than the recommended values (1-2 mg/L) (WHO, 1989). Apart from this, the bio-chemical oxygen demand (BOD) of the greywater appeared to be slightly higher than the recommended values of Platzer et al. (2004). Similar scenario was evident for the chemical oxygen demand (COD) indicating the ability of the water to degrade organic waste and to consume oxygen though chemical reaction. During the entire growing seasons of the consecutive years, the water temperature ranged from $18-30{ }^{\circ} \mathrm{C}$. The greywater used in this study was found to be containing lower level $(482 \pm 75 \mathrm{mg} / \mathrm{L})$ of dissolved solids which is indicative of lower salinity level.

Table 04. Concentration (mean \pm SD) of different parameters present in greywater

\begin{tabular}{|l|l|l|l|}
\hline Parameter & Concentration & Parameter & Concentration \\
\hline Potassium $(\mathrm{K})$ & $17.0 \pm 1.3 \mathrm{mg} / \mathrm{L}$ & Phosphate $\left(\mathrm{PO}_{4}\right)$ & $6.0 \pm 1.1 \mathrm{mg} / \mathrm{L}$ \\
\hline Sodium $(\mathrm{Na})$ & $24 \pm 3 \mathrm{mg} / \mathrm{L}$ & Sulphate $\left(\mathrm{SO}_{4}\right)$ & $<50 \mathrm{mg} / \mathrm{L}$ \\
\hline Calcium $(\mathrm{Ca})$ & $16.8 \pm 4.1 \mathrm{mg} / \mathrm{L}$ & SAR & $5.8 \pm 0.8 \mathrm{mg} / \mathrm{L}$ \\
\hline Chloride $(\mathrm{Cl})$ & $44 \pm 7.3 \mathrm{mg} / \mathrm{L}$ & Total Alkalinity & $244 \pm 21 \mathrm{mg} / \mathrm{L}$ \\
\hline Zinc $(\mathrm{Zn})$ & $2 \pm 0.6 \mathrm{mg} / \mathrm{L}$ & Total Dissolved Solid & $482 \pm 75 \mathrm{mg} / \mathrm{L}$ \\
\hline Iron $(\mathrm{Fe})$ & $2.2 \pm 0.3 \mathrm{mg} / \mathrm{L}$ & BOD $_{5}$ & $150 \pm 11 \mathrm{mg} / \mathrm{L}$ \\
\hline Magnesium $(\mathrm{Mg})$ & $17.8 \pm 4.0 \mathrm{mg} / \mathrm{L}$ & COD & $232 \pm 17 \mathrm{mg} / \mathrm{L}$ \\
\hline
\end{tabular}

\section{Effect of wastewater on production}

\section{Mungbean}

The effect of greywater on the production of mungbean was found to be significantly varying. Analysis of the morphological characters of mungbean revealed that the highest average plant height (44.17 $\mathrm{cm}$ ) and straw production (2.79 t/ha) was obtained (Figure 01) for the freshwater treatment (T1) while, the lowest plant height $(31.08 \mathrm{~cm})$ and straw yield $(2.61 \mathrm{t} / \mathrm{ha})$ was obtained from the raw application of wastewater (T2). 


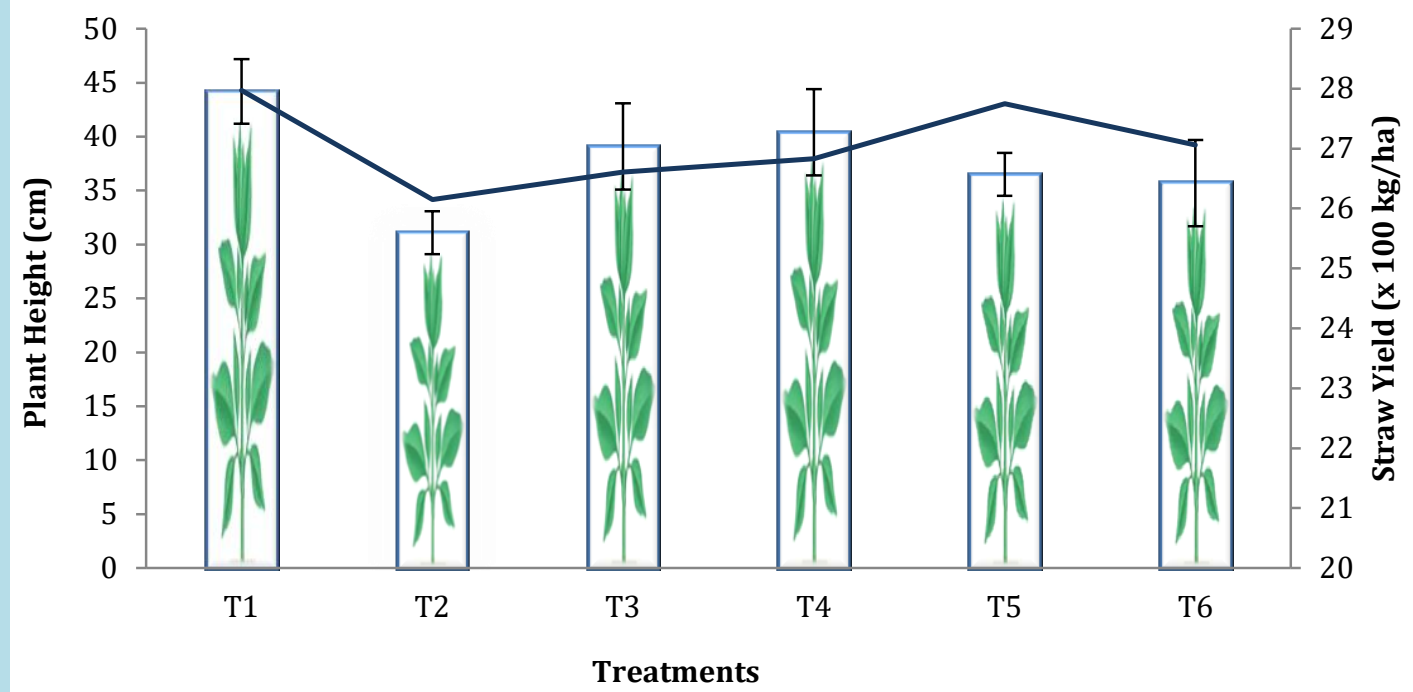

Figure 01. Variation in the plant height and straw yield of Mungbean under different greywater treatments.

The pod lengths in mungbean ultimately translate into the total number of seeds to be obtained from a plant. In case of treatment T2 $(100 \%$ greywater), the average pod length $(8.68 \mathrm{~cm})$ came to be the lowest indicating a lower yield potential. Similar trend was also followed by the number of seeds obtained from each of the pods. Thousand grain weight, an important indication of yield, at 8\% moisture content, was found to be the highest for the treatment $\mathrm{T} 4 \mathrm{25 \%}$ fresh water $+75 \%$ wastewater) which, in turn, reflected into the highest grain yield (1504 kg/ha).

Table 05. Yield and yield contributing characters of Mungbean under different treatments

\begin{tabular}{|l|l|l|l|l|l|}
\hline Treatment & $\begin{array}{l}\text { Plant height } \\
(\mathrm{cm})\end{array}$ & $\begin{array}{l}\text { Pod length } \\
(\mathrm{cm})\end{array}$ & $\begin{array}{l}\text { No. of grain } \\
\text { per pod }\end{array}$ & $\begin{array}{l}1000 \text { grain } \\
\text { weight }(\mathrm{kg})\end{array}$ & $\begin{array}{l}\text { Grain yield } \\
(\mathrm{kg} / \mathrm{ha})\end{array}$ \\
\hline T1 & 44.2 & 8.7 & 10.9 & 41.4 & $1314_{\mathbf{b}}$ \\
\hline T2 & 31.1 & 8.7 & 10.5 & 40.0 & $1036_{\mathbf{d}}$ \\
\hline T3 & 39.1 & 8.9 & 10.7 & 40.7 & $1162_{\mathbf{c d}}$ \\
\hline T4 & 40.4 & 9.9 & 10.6 & 43.2 & $1504_{\mathbf{a}}$ \\
\hline T5 & 36.5 & 9.1 & 10.0 & 41.4 & $1308_{\mathbf{b}}$ \\
\hline T6 & 35.7 & 9.0 & 10.9 & 40.7 & $1280_{\mathbf{b c}}$ \\
\hline$L S D(5 \%)$ & 9.5 & 2.4 & 1.3 & 5.2 & 143.2 \\
\hline \multicolumn{5}{|l}{ Lettered numbers are statistically significant at $\mathrm{p}=0.05$ (analyzed using GENSTAT) } \\
\hline
\end{tabular}

Moderate grain yield (1162 kg/ha) was obtained in case of irrigation with the treated water (T3) by alum. The results also showed that taller plants under freshwater irrigation provided moderate yields. On the other hand, a combination of fresh water and greywater provided higher yield of mungbean. This is indicative of the ability of greywater to provide for the critical nutritive requirements of the plants supplementing the regular supply from the soil. However, exclusive use of raw greywater as irrigation may not be beneficial for mungbean plants as can be seen from the lower yield potential of treatment T2 (1036 kg/ha) in Table 05.

\section{Wheat}

Analysis of the morphological characters of wheat has been shown in Table 06. The highest average plant height $(94 \mathrm{~cm})$ was obtained for the treatment T4 while, the lowest $(81 \mathrm{~cm})$ was obtained from the treatment T3. In case of treatment T4 which is the combined treatment of freshwater $(25 \%)$ and greywater $(75 \%)$, the average panicle length $(9.8 \mathrm{~cm})$ also came to be the highest indicating a higher yield potential. Almost similar trend was also followed by the number of seeds obtained from each of the panicles (Table 06). The thousand grain weight at $12 \%$ moisture content, was also found to be highest for the treatment $\mathrm{T} 4$ which produced the highest grain yield $(1.85 \mathrm{t} / \mathrm{ha})$. 
Table 06. Yield and yield contributing characters of wheat under different treatments

\begin{tabular}{|l|l|l|l|l|l|l|}
\hline Treatment & $\begin{array}{l}\text { Plant } \\
\text { height } \\
(\mathrm{cm})\end{array}$ & $\begin{array}{l}\text { Panicle } \\
\text { length } \\
(\mathrm{cm})\end{array}$ & $\begin{array}{l}\text { No. of } \\
\text { grain per } \\
\text { panicle }\end{array}$ & $\begin{array}{l}100 \text { grain } \\
\text { weight } \\
(\mathrm{kg})\end{array}$ & $\begin{array}{l}\text { Grain } \\
\text { yield } \\
(\mathrm{kg} / \mathrm{ha})\end{array}$ & $\begin{array}{l}\text { Straw } \\
\text { yield } \\
(\mathrm{kg} / \mathrm{ha})\end{array}$ \\
\hline T1 & 86.87 & 9.26 & 32.00 & 4.80 & $1590_{\mathrm{c}}$ & 2610 \\
\hline T2 & 85.67 & 9.13 & 34.27 & 4.83 & $1733_{\mathrm{b}}$ & 3166 \\
\hline T3 & 81.80 & 9.53 & 34.93 & 4.63 & $1616_{\mathrm{c}}$ & 2300 \\
\hline T4 & 94.00 & 9.78 & 39.13 & 4.90 & $1850_{\mathrm{a}}$ & 2966 \\
\hline T5 & 83.13 & 9.77 & 35.53 & 4.63 & $1566_{\mathrm{cd}}$ & 2850 \\
\hline T6 & 84.47 & 9.78 & 37.20 & 4.77 & $1400_{\mathrm{d}}$ & 2385 \\
\hline LSD (5\%) & 21.51 & 1.25 & 8.10 & 0.58 & 634 & 1611 \\
\hline
\end{tabular}

The performance of treated greywater (T3) was not in the moderate range as it produced 1.6 t/ha of wheat. It was observed that none of the freshwater treatment (T1) or the raw greywater treatment (T2) contributed to the highest yield. Therefore, in order to obtain higher yield of wheat, a mixture of raw greywater and fresh groundwater offers better economic advantages over freshwater or alumtreated water. Nonetheless, the alum-treated greywater might (T3) offer some health benefits (Casanova et al., 2001) to the farmers as some of the organics are removed by the coagulation process. Moreover, as can be seen from Table 06, treated water may not jeopardize the economic return of crops.

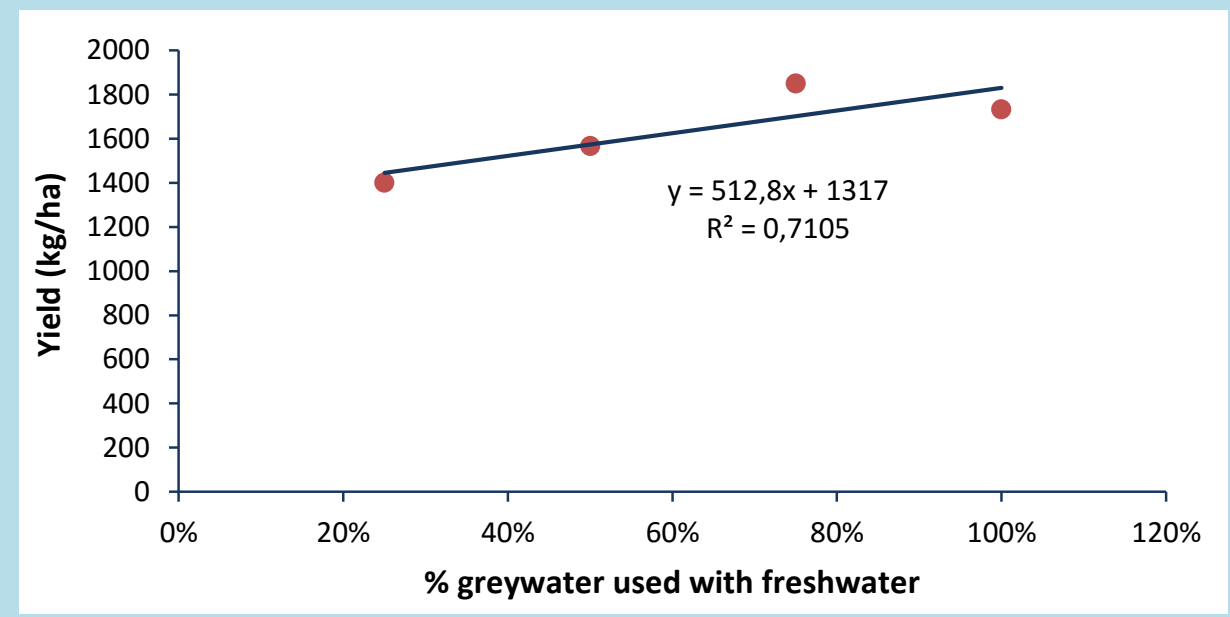

Figure 02. Increasing yield of Wheat with the increase of greywater use in irrigation

In case of combined use of wastewater and fresh irrigation water, as the greywater concentration increased from treatment T6 to T4, the yield of wheat also increased steadily (Figure 02). Application of raw wastewater in the field (T2) was found satisfactory as it gave the second highest yield (1.73 $\mathrm{t} / \mathrm{ha}$ ). The overall results from greywater treatments on mungbean and wheat suggest that the alumtreated greywater can be a very fruitful alternative as it provides moderate yield in addition to health benefits (FAO, 2003).

\section{Effect on soil nutritional balance}

For the purpose of irrigation scheduling, the apparent specific gravity (As) and the available moisture holding capacity of the newly developed soil was found to be 1.44 , and $42.63 \mathrm{~cm} / \mathrm{m}$ - depth of soil, respectively. With $20 \%$ sand, $41 \%$ silt and $39 \%$ clay content, it was identified to be a clayey loam soil (Minasny \& McBratney, 2001). The soil was tested to find out any changes in the soil nutritional balance. The greywater experiment on mungbean was carried out in the first year (Year 1) followed by the experiment on wheat at the same season next year (Year 2). The soil data of Year 1 is the preliminary data obtained before the cultivation of mungbean. On the other hand, the data of Year 2 in Table 07 is the result of soil analysis after the harvest of wheat, i. e., Year 2 data shows the accumulative effect of greywater irrigation on the soil for two consecutive years. Considering the potential outcome of treatment $\mathrm{T} 4$ in the greywater experiments, the following Table 07 has been 
prepared from the analysis of the soil that received T4 only (75\% greywater irrigation $+25 \%$ fresh groundwater).

The results showed that, soil was working as bio-filter as it reduced a large part of the greywater pollutions. However, such filtering increased salinity of the soil as the EC raised by almost 0.152 $\mathrm{dS} / \mathrm{m} /$ year (Table 07) despite a rainy season between the two consecutive years. This means continuous greywater irrigation will inevitably increase the soil salinity unless heavy downpours can create runoffs large enough to leach out the excess salts. Several studies have shown that the salinity problem is agricultural soils are often connected with poor drainage systems (Kiremit \& Arslan, 2016; Valipour, 2014). Therefore, before introducing greywater irrigation in any area, the agricultural drainage system must be given a priority.

Table 07. Soil nutrient content before and after Mungbean cultivation with wastewater

\begin{tabular}{|l|l|l|l|}
\hline \multirow{2}{*}{ Parameters } & \multirow{2}{*}{ Unit } & Results \\
\cline { 3 - 4 } & & Year 1 & Year 2 \\
\hline $\mathrm{EC}$ & $\mathrm{dS} / \mathrm{m}$ & 0.568 & 0.871 \\
\hline $\mathrm{PH}$ & - & 7.2 & 7.41 \\
\hline $\mathrm{Ca}$ & $\mathrm{meq} / 100$ gm soil & 12.01 & 14.02 \\
\hline $\mathrm{Mg}$ & $\mathrm{meq} / 100$ gm soil & 14.12 & 16.17 \\
\hline $\mathrm{K}$ & $\mathrm{meq} / 100$ gm soil & 201.41 & 208.4 \\
\hline $\mathrm{P}$ & $\mu \mathrm{g} / \mathrm{gm}$ soil & 5.12 & 12.14 \\
\hline $\mathrm{Na}$ & $\mu \mathrm{g} / \mathrm{gm}$ soil & 30.21 & 37.21 \\
\hline $\mathrm{Bo}$ & $\mu \mathrm{g} / \mathrm{gm}$ soil & 0.28 & 0.31 \\
\hline $\mathrm{Fe}$ & $\mu \mathrm{g} / \mathrm{gm}$ soil & 38.0 & 42 \\
\hline $\mathrm{SAR}$ & - & 8.72 & 9.92 \\
\hline
\end{tabular}

The concentration of other nutrients (NPK) in soil was also found to have increased due to greywater irrigation. Similar phenomenon has been reported by several researchers (Mzini \& Winter, 2015; Pandey et al., 2014). The concentration of phosphorus, in particular, was found to have doubled in the soil during the greywater irrigation. Such buildup of $\mathrm{P}$ has been a significant concern for the environment. Turner et al. (2013) suggested that sustainable greywater reuse is possible however incorrect use can result in phosphorus impacting the environment. Therefore, crops that are efficient in $\mathrm{P}$ uptake should be cultivated with greywater irrigation. Moreover, as a protective measure, greywater can be diluted furthermore in order to lower the salt content (Mzini \& Winter, 2015).

$\mathrm{Ca}, \mathrm{Mg}$ and $\mathrm{Fe}$ concentration of the soil also increased (Table 07) due to greywater irrigation. Fe concentration in particular increased by $2 \mathrm{ppm} /$ year. However, such a general conclusion cannot be made in case of greywater irrigation. This is because it all depends on the type of soil and the crop's efficiency to remove nutrients from the media. Therefore, a site specific investigation with greywater and particular soil type is always recommended. Particular focus must also be given to the sodium content of soil as the greywater irrigated plots had significantly higher SAR values compared to the non-irrigated plots. This could be because of the type of soil (clayey loam) in this experiment. Nonetheless, it provided reasons for concern about possible reductions in soil hydraulic conductivity due to long term use of greywater. In such case salt leaching would become less effective and infiltration rate will be reduced. This study strongly recommends that future studies be directed into this area of apprehension.

\section{Conclusion}

Greywater can be a viable and alternative source of irrigation water in Bangladesh. However, the apprehension of possible negative effects of greywater on the soil and the environment has not been addressed in the literature. This study reports the results of two separate agronomic experiments carried out to quantify the effects of greywater irrigation on the production of two popular winter crops in Bangladesh i.e., mungbean and wheat. The experimental findings highlighted the fact that raw use of greywater was not beneficial for mungbean. On the other hand, second highest yield of wheat was obtained from the raw greywater treatment. Nonetheless, the highest crop yield was found when greywater $(75 \%)$ was diluted with freshwater $(25 \%)$ in a combined use. The yield potential of the 
studied crops was found be increasing with the increase of greywater percentage in case of combined use. Crops irrigated with alum-treated greywater produced moderate yields, hence could be a cheap and effective choice for the farmers considering the health benefit that it offers. It was found that unregulated use of greywater resource could lead to salinity problems and reduction in hydraulic conductivity of the soil. In particular, greywater irrigation was shown to be leading a buildup of $P$ in the soil which could pose a potential environmental risk. This study recommends that crops good at up taking phosphorus from the soil should be prioritized if grown under greywater condition. Further studies are, therefore, needed in this regard with different crops involving various soil types so as to quantify the effect of greywater irrigation in wider perspectives.

\section{Acknowledgement}

The authors would like to acknowledge the Research Management Committee (RMC) of Bangabandhu Sheikh Mujibur Rahman Agricultural University for funding this research program. The Soil Resource Development Institute (SRDI), Dhaka is also hereby acknowledged for aiding in chemical analysis of the soil and water samples.

\section{References}

[1] Ahmad, J. U. \& Goni, M. A. (2010). Heavy metal contamination in water, soil, and vegetables of the industrial areas in Dhaka, Bangladesh. Environmental Monitoring and Assessment, 166(14), 347-357. http://dx.doi.org/10.1007/s10661-009-1006-6

[2] Al-Wabel, M. I. (2011). Simple system for handling and reuse of gray water resulted from ablution in Mosques of Riyadh City, Saudi Arabia. Paper presented at the Proceedings of International Conference on Environment Science and Engineering, IPCBEE.

[3] APHA. (2005). Standard methods for the examination of water and wastewater. In: A. D. Eaton, L. S. Clesceri, E. W. Rice, A. E. Greenberg, \& M. A. H. Franson (Eds.), (21 ed.). Washington DC.: American Public Health Association Press.

[4] ASTM. (2010). Standard Test Method for Elements in Water by Inductively Coupled PlasmaMass Spectrometry. West Conshohocken, PA, www.astm.org.: ASTM Standard D5673-10, ASTM International.

[5] ASTM. (2012). Standard Practice for Sample Digestion Using Closed Vessel Microwave Heating Technique for the Determination of Total Metals in Water. West Conshohocken, PA, www.astm.org: ASTM Standard D4309, ASTM International.

[6] BARC. (2005). Fertilizer recommendation guide. In M. Miah, et al. (Ed.), Soils Publication (Vol. 45). Dhaka: Bangladesh Agricultural Research Council.

[7] BBS. (2015). Bangladesh Bureau of Statistics - Population monograph of Bangladesh population density and vulnerability: a challenge for sustainable development. Government of the People's Republic of Bangladesh.

[8] Casanova, L. M., Gerba, C. P. \& Karpiscak, M. (2001). Chemical and microbial characterization of household graywater. Journal of Environmental Science and Health, Part A, 36(4), 395-401. http://dx.doi.org/10.1081/ESE-100103471

[9] Christova-Boal, D., Eden, R. E. \& McFarlane, S. (1996). An investigation into greywater reuse for urban residential properties. Desalination, 106(1), 391-397.

http://dx.doi.org/10.1016/S0011-9164(96)00134-8

[10] EPA Victoria. (2003). Guidelines for Environmental Management: Use of Reclaimed Water (Vol. 464.2). Victoria, Australia: EPA Victoria.

[11] Eriksson, E., Auffarth, K., Henze, M. \& Ledin, A. (2002). Characteristics of grey wastewater. Urban water, 4(1), 85-104. http://dx.doi.org/10.1016/S1462-0758(01)00064-4

[12] FAO. (2003). User Manual for Irrigation with Treated Wastewater Irrigation with wastewater. Y5009. Food and Agriculture Organisation of the United Nations, Regional Office for the Near East. Cairo.

[13] Friedler, E. (2004). Quality of individual domestic greywater streams and its implication for on-site treatment and reuse possibilities. Environmental technology, 25(9), 997-1008.

http://dx.doi.org/10.1080/09593330.2004.9619393 
[14] Friedler, E., Katz, I. \& Dosoretz, C. G. (2008). Chlorination and coagulation as pretreatments for greywater desalination. Desalination, 222(1), 38-49.

http://dx.doi.org/10.1016/j.desal.2007.01.130

[15] Jarwal, S., Bolanda, A. M., Stevensb, D. \& Faggian, R. (2006). Using Recycled Water in Horticulture: A Growers Guide. Retrieved from Melbourne:

[16] Khatun, A., \& Amin, M. (2011). Greywater reuse: a sustainable solution for water crisis in Dhaka, Bangladesh. ISBN: 978-984-33, 4363.

[17] Kiremit, M. S. \& Arslan, H. (2016). Effects of irrigation water salinity on drainage water salinity, evapotranspiration and other leek (Allium porrum L.) plant parameters. Scientia Horticulturae, 201, 211-217. http://dx.doi.org/10.1016/j.scienta.2016.02.001

[18] Kunhikrishnan, A., Bolan, N. S., Müller, K., Laurenson, S., Naidu, R. \& Kim, W.-I. (2012). Chapter Five - The Influence of Wastewater Irrigation on the Transformation and Bioavailability of Heavy Metal(Loid)s in Soil. In L. S. Donald (Ed.), Advances in Agronomy (Vol. 115, pp. 215297): Academic Press.

[19] Li, F., Wichmann, K. \& Otterpohl, R. (2009). Review of the technological approaches for grey water treatment and reuses. Science of the Total Environment, 407(11), 3439-3449. http://dx.doi.org/10.1016/j.scitotenv.2009.02.004

[20] Minasny, B. \& McBratney, A. B. (2001). The australian soil texture boomerang: a comparison of the australian and usda/fao soil particle-size classification systems. Soil Research, 39(6), 1443-1451. http://dx.doi.org/10.1071/SR00065

[21] Mzini, L. L. \& Winter, K. (2015). Analysis of grey-water used for irrigating vegetables and possible effects on soils in the vicinity of Umtata Dam, Eastern Cape. Water SA, 41(1), 115120. http://dx.doi.org/10.4314/wsa.v41i1.14

[22] Oliver, M. M. H., Hewa, G. A. \& Pezzaniti, D. (2014). Bio-fouling of subsurface type drip emitters applying reclaimed water under medium soil thermal variation. Agricultural Water Management, 133, 12-23. http://dx.doi.org/10.1016/j.agwat.2013.10.014

[23] Pandey, A., Srivastava, R. \& Singh, P. (2014). Short-term impacts of gray water irrigation on soil characteristics in land-treatment vegetation filters. Communications in soil science and plant analysis, 45(10), 1305-1315. http://dx.doi.org/10.1080/00103624.2013.875196

[24] Pidou, M., Avery, L., Stephenson, T., Jeffrey, P., Parsons, S. A., Liu, S., Jefferson, B. (2008). Chemical solutions for greywater recycling. Chemosphere, 71(1), 147-155. http://dx.doi.org/10.1016/j.chemosphere.2007.10.046

[25] Platzer, M., Cáceres, V. \& Fong, N. (2004). The reuse of treated wastewater for agricultural purposes in Nicaragua; Central America. Water Science \& Technology, 50(2), 293-300.

[26] Prathapar, S., Ahmed, M., Al Adawi, S. \& Al Sidiari, S. (2006). Design, construction and evaluation of an ablution water treatment unit in Oman: a case study. International journal of environmental studies, 63(3), 283-292. http://dx.doi.org/10.1080/00207230600773257

[27] SA Health. (2012). Guidelines for the carting of recycled water. Adelaide: Department of Health, Government of South Australia.

Retrieved from www.health.sa.gov.au/pehs/environ-health-index.htm.

[28] Skudi, J., Wanjau, R., Murungi, J. \& Onindo, C. (2011). Alum Treated Grey Water for Toilet Flushing, Mopping and Laundry Work. Hydrol Current Res, 2(114), 2. http://dx.doi.org/10.4172/2157-7587.1000114

[29] Šostar-Turk, S., Petrinić, I. \& Simonič, M. (2005). Laundry wastewater treatment using coagulation and membrane filtration. Resources, Conservation and Recycling, 44(2), 185-196. http://dx.doi.org/10.1016/j.resconrec.2004.11.002

[30] Tamanna, M., Jalil, M. A., Islam, S. \& Anam, S. (2011). Greywater Generation and Quality Measurement at a Specific Site in Dhaka City. Undergraduate thesis, Bangladesh University of Engineering and Technology.

[31] Terpstra, P. (1999). Sustainable water usage systems: models for the sustainable utilization of domestic water in urban areas. Water Science and Technology, 39(5), 65-72. http://dx.doi.org/10.1016/S0273-1223(99)00088-8

[32] Thamsen, P. U. (2009). Cutting clogging in wastewater. World Pumps, 2009 (511), 22-25. http://dx.doi.org/10.1016/S0262-1762(09)70140-3

[33] Trooien, T. P. \& Hills, D. J. (2007). Application of Biological Effluent. In F. R. Lamm, J. E. Ayars, \& F. S. Nakayama (Eds.), Microirrigation for Crop Production. Design, Operation and Management (Vol. 13, pp. 333-341). Amsterdam: Elsevier. 
http://dx.doi.org/10.1016/S0167-4137(07)80012-6

[34] Turner, R. D., Will, G. D., Dawes, L. A., Gardner, E. A. \& Lyons, D. J. (2013). Phosphorus as a limiting factor on sustainable greywater irrigation. Science of the Total Environment, 456, 287298. http://dx.doi.org/10.1016/j.scitotenv.2013.02.061

[35] Valipour, M. (2014). Drainage, waterlogging, and salinity. Archives of Agronomy and Soil Science, 60(12), 1625-1640. http://dx.doi.org/10.1080/03650340.2014.905676

[36] Vanhaecke, F. (2002). ICP-MS. Analytical and Bioanalytical Chemistry, 372(1), 20-21. http://dx.doi.org/10.1007/s00216-001-1147-0

[37] Voica, C., Kovacs, M. H., Dehelean, A., Ristoiu, D. \& Iordache, A. (2012). ICP-MS determinations of heavy metals in surface waters from Transylvania. Romanian Journal of Physics, 57(7-8), 1184-1193.

[38] WHO. (1989). Health guidelines for the use of wastewater in agriculture and aquaculture. Technical Report No. 778. Geneva.

[39] Zavala, M. L., Funamizu, N. \& Takakuwa, T. (2002). Onsite wastewater differential treatment system: modeling approach. Water Science and Technology, 46(6-7), 317-324. 